\title{
Grouping of nanomaterials for risk assessment
}

\author{
Hermann M. Bolt
}

Published online: 21 November 2014

(C) Springer-Verlag Berlin Heidelberg 2014

In this issue of the archives of toxicology, Gebel and colleagues introduce a practical guide how to group nanomaterials for risk assessment (Gebel et al. 2014). To establish categories, the authors analyzed exposure scenarios where nanoparticles have been shown to cause adverse health effects. Particularly, critical is exposure by inhalation, when nanoparticles belong to one of the following two groups: (1) Rigid biopersistent respirable fibrous nanoparticles with a high aspect ratio, the so-called WHO fibers. This type of nanoparticles may cause lung cancer and mesotheliomas upon inhalation by similar mechanisms as reported for asbestos. (2) Respirable granular biodurable particles. Also, this type of nanomaterial may cause inflammation and secondary mutagenicity after inhalation in the lung. (3) Nanoparticles for which toxicity is mediated by the specific chemical properties of its components. Examples are functional groups on the particle surface or released ions. Particles belonging to this group have to be evaluated caseby-case. In contrast to the first two categories, this applies to all routes of exposure.

Currently, nanotoxicology is one of the most popular fields in toxicology (Clift et al. 2014; Zhao et al. 2014; Lucafò et al. 2013; Silva et al. 2014; Couto et al. 2014; Setyawati et al. 2013; Fadeel et al. 2013), and also, a relatively high number of manuscripts on this topic have recently published in our journal (Bolt et al. 2012; Schäfer et al. 2013; Bondarenko et al. 2013; Horie et al. 2013; Xu et al. 2013). Ongoing studies analyze the impact of size and shape (Park et al. 2013; Xiong et al. 2013; Zhao et al.

H. M. Bolt $(\square)$

Leibniz Research Centre for Working Environment and Human

Factors, Technical University of Dortmund (IfADo),

44139 Dortmund, Germany

e-mail: bolt@ifado.de
2013; Schluesener and Schluesener 2013), study the biokinetics (Landsiedel et al. 2012; Klein et al. 2012) or establish in vitro systems for testing of nanomaterials (Hoelting et al. 2013; Haase et al. 2012; Kroll et al. 2012). However, because of the high number of different materials and the difficulty to interpret many of the in vitro studies with respect to their in vivo relevance, the present categorization concept proposed by Gebel et al. (2014) will contribute to a better overview and a more straightforward hazard identification. When novel nanomaterials have to be evaluated, it seems reasonable to check initially whether they fulfill one of the three "Gebel-criteria." Besides introducing the novel categorization concept, the review addresses the question whether nanomaterials act by novel mechanisms. The authors conclude that despite the intensive research in this field, not a single "nanospecific" mechanism of action has been identified so far. All molecular mechanisms described for nanomaterials have already been identified for chemicals or described in conventional particle toxicology. The present article (Gebel et al. 2014) is of high interest to anyone working in the field of nanotoxicity, because it introduces a straightforward concept and gives the risk evaluator a better overview.

\section{References}

Bolt HM, Marchan R, Hengstler JG (2012) Nanotoxicology and oxidative stress control: cutting-edge topics in toxicology. Arch Toxicol 86(11):1629-1635

Bondarenko O, Juganson K, Ivask A, Kasemets K, Mortimer M, Kahru A (2013) Toxicity of $\mathrm{Ag}, \mathrm{CuO}$ and $\mathrm{ZnO}$ nanoparticles to selected environmentally relevant test organisms and mammalian cells in vitro: a critical review. Arch Toxicol 87(7):1181-1200

Clift MJ, Endes C, Vanhecke D, Wick P, Gehr P, Schins RP, Petri-Fink A, Rothen-Rutishauser B (2014) A comparative study of different in vitro lung cell culture systems to assess the most beneficial 
tool for screening the potential adverse effects of carbon nanotubes. Toxicol Sci 137(1):55-64

Couto D, Freitas M, Vilas-Boas V, Dias I, Porto G, Lopez-Quintela MA, Rivas J, Freitas P, Carvalho F, Fernandes E (2014) Interaction of polyacrylic acid coated and non-coated iron oxide nanoparticles with human neutrophils. Toxicol Lett 225(1):57-65

Fadeel B, Alenius H, Savolainen K (2013) Nanotoxicology. Toxicology 313(1):1-2

Gebel T, Foth H, Damm G, Freyberger A, Kramer PJ, Lilienblum W, Röhl C, Schupp T, Weiss C, Wollin KM, Hengstler JG (2014) Manufactured nanomaterials: categorization and approaches to hazard assessment. Arch Toxicol. doi:10.1007/s00204-014-13837 [Epub ahead of print]

Haase A, Mantion A, Graf P, Plendl J, Thuenemann AF, Meier W, Taubert A, Luch A (2012) A novel type of silver nanoparticles and their advantages in toxicity testing in cell culture systems. Arch Toxicol 86(7):1089-1098

Hoelting L, Scheinhardt B, Bondarenko O, Schildknecht S, Kapitza M, Tanavde V, Tan B, Lee QY, Mecking S, Leist M, Kadereit S (2013) A 3-dimensional human embryonic stem cell (hESC)derived model to detect developmental neurotoxicity of nanoparticles. Arch Toxicol 87(4):721-733

Horie M, Kato H, Iwahashi H (2013) Cellular effects of manufactured nanoparticles: effect of adsorption ability of nanoparticles. Arch Toxicol 87(5):771-781

Klein CL, Wiench K, Wiemann M, Ma-Hock L, van Ravenzwaay B, Landsiedel R (2012) Hazard identification of inhaled nanomaterials: making use of short-term inhalation studies. Arch Toxicol 86(7):1137-1151

Kroll A, Pillukat MH, Hahn D, Schnekenburger JU (2012) Interference of engineered nanoparticles with in vitro toxicity assays. Arch Toxicol 86(7):1123-1136

Landsiedel R, Fabian E, Ma-Hock L, van Ravenzwaay B, Wohlleben W, Wiench K, Oesch F (2012) Toxico-/biokinetics of nanomaterials. Arch Toxicol 86(7):1021-60. doi:10.1007/s00204-012-08587. Review. Erratum in: Arch Toxicol 86(7):1061
Lucafò M, Gerdol M, Pallavicini A, Pacor S, Zorzet S, Da Ros T, Prato M, Sava G (2013) Profiling the molecular mechanism of fullerene cytotoxicity on tumor cells by RNA-seq. Toxicology 314(1):183-192

Park EJ, Shim HW, Lee GH, Kim JH, Kim DW (2013) Comparison of toxicity between the different-type $\mathrm{TiO}_{2}$ nanowires in vivo and in vitro. Arch Toxicol 87(7):1219-1230

Schäfer B, Brocke JV, Epp A, Götz M, Herzberg F, Kneuer C, Sommer Y, Tentschert J, Noll M, Günther I, Banasiak U, Böl GF, Lampen A, Luch A, Hensel A (2013) State of the art in human risk assessment of silver compounds in consumer products: a conference report on silver and nanosilver held at the BfR in 2012. Arch Toxicol 87(12):2249-2262

Schluesener JK, Schluesener HJ (2013) Nanosilver: application and novel aspects of toxicology. Arch Toxicol 87(4):569-576

Setyawati MI, Tay CY, Leong DT (2013) Effect of zinc oxide nanomaterials-induced oxidative stress on the $\mathrm{p} 53$ pathway. Biomaterials 34(38):10133-10142

Silva T, Pokhrel LR, Dubey B, Tolaymat TM, Maier KJ, Liu X (2014) Particle size, surface charge and concentration dependent ecotoxicity of three organo-coated silver nanoparticles: comparison between general linear model-predicted and observed toxicity. Sci Total Environ 468-469:968-976

Xiong S, George S, Yu H, Damoiseaux R, France B, Ng KW, Loo JS (2013) Size influences the cytotoxicity of poly (lactic-co-glycolic acid) (PLGA) and titanium dioxide $\left(\mathrm{TiO}_{2}\right)$ nanoparticles. Arch Toxicol 87(6): 1075-1086

Xu J, Li Z, Xu P, Xiao L, Yang Z (2013) Nanosized copper oxide induces apoptosis through oxidative stress in podocytes. Arch Toxicol 87(6):1067-1073

Zhao X, Ng S, Heng BC, Guo J, Ma L, Tan TT, Ng KW, Loo SC (2013) Cytotoxicity of hydroxyapatite nanoparticles is shape and cell dependent. Arch Toxicol 87(6):1037-1052

Zhao B, Sun L, Zhang W, Wang Y, Zhu J, Zhu X, Yang L, Li C, Zhang Z, Zhang Y (2014) Secretion of intestinal goblet cells: a novel excretion pathway of nanoparticles. Nanomedicine 10(4):839-849 